\title{
Magnetic Steel Slag Biochar for Ammonium Nitrogen Removal from Aqueous Solution
}

\author{
Gyuhyeon Kim ${ }^{1}{ }^{1}$, Young Mo Kim ${ }^{2}$, Su Min Kim ${ }^{3}$, Hyun Uk Cho ${ }^{3, *}$ and Jong Moon Park ${ }^{1,4,5,6, *}$ \\ 1 Division of Advanced Nuclear Engineering, Pohang University of Science and Technology, \\ Pohang 37673, Korea; kyubba@postech.ac.kr \\ 2 Department of Civil and Environmental Engineering, Hanyang University, Seongdong-gu, \\ Seoul 04763, Korea; youngmo@hanyang.ac.kr \\ 3 Department of Marine Environmental Engineering, Gyeongsang National University, Jinju-si 53064, Korea; \\ ksm98@gnu.ac.kr \\ 4 School of Environmental Science and Engineering, Pohang University of Science and Technology, \\ Pohang 37673, Korea \\ 5 Department of Chemical Engineering, Pohang University of Science and Technology, Pohang 37673, Korea \\ 6 School of Integrated Technology, Yonsei University (POSTECH-Yonsei Open Campus), Pohang 37673, Korea \\ * Correspondence: hucho@gnu.ac.kr (H.U.C.); jmpark@postech.ac.kr (J.M.P.); \\ Tel.: +82-55-772-9133 (H.U.C.); +82-54-279-2275 (J.M.P.)
}

Citation: Kim, G.; Kim, Y.M.; Kim, S.M.; Cho, H.U.; Park, J.M. Magnetic Steel Slag Biochar for Ammonium Nitrogen Removal from Aqueous Solution. Energies 2021, 14, 2682. https://doi.org/10.3390/en14092682

Academic Editor: Antonio Zuorro

Received: 27 March 2021

Accepted: 4 May 2021

Published: 7 May 2021

Publisher's Note: MDPI stays neutral with regard to jurisdictional claims in published maps and institutional affiliations.

Copyright: (c) 2021 by the authors. Licensee MDPI, Basel, Switzerland. This article is an open access article distributed under the terms and conditions of the Creative Commons Attribution (CC BY) license (https:/ / creativecommons.org/licenses/by/ $4.0 /)$.

\begin{abstract}
In this study, magnetic steel slag biochar (MSSB) was synthesized from low-cost steel slag waste to investigate the effectiveness of steel slag biochar composite for $\mathrm{NH}_{4}-\mathrm{N}$ removal and magnetic properties in aqueous solution. The maximum adsorption capacity of $\mathrm{NH}_{4}-\mathrm{N}$ by MSSB was $4.366 \mathrm{mg} / \mathrm{g}$ according to the Langmuir model. The magnetic properties of MSSB indicated paramagnetic behavior and a saturation magnetic moment of $2.30 \mathrm{emu} / \mathrm{g}$ at 2 Tesla. $\mathrm{The}^{\mathrm{N}} \mathrm{NH}_{4}-\mathrm{N}$ adsorption process was well characterized by the pseudo-second order kinetic model and Temkin isotherm model. This study demonstrated the potential of magnetic biochar synthesized from steel slag waste for $\mathrm{NH}_{4}-\mathrm{N}$ removal in aqueous solution.
\end{abstract}

Keywords: magnetic biochar; steel slag; ammonium nitrogen; adsorption; magnetic properties

\section{Introduction}

Due to the development of steel industries, the annual domestic generation of crude steel in South Korea reached about 71 million tons in 2019 and it has shown an increasing trend over the years. [1] However, steel industries also produce a considerable amount of waste materials. Particularly, steel slag is produced as a byproduct from steel-making and refining processes and occupies about $40 \%$ of annual steel output in South Korea [2]. For decades, the proper treatment or reuse of steel slag has become an issue and steel industries are seeking efficient techniques to reclaim it $[3,4]$.

Basic oxygen furnace (BOF) slag mainly consists of $\mathrm{SiO}_{2}, \mathrm{CaO}, \mathrm{Fe}_{2} \mathrm{O}_{3}, \mathrm{Al}_{2} \mathrm{O}_{3}$, and some alkaline substances. It has been used as lime, silicate, and iron fertilizer [5-8]. However, there is a limit to the broad application of raw BOF slag as fertilizers because of nitrogen deficiency. In general, nitrogen is an essential component for plant growth and nitrogen fertilizer is expensive [9].

Biochar is solid biomass such as wood, crop residues, or agricultural waste that is pyrolyzed under oxygen-free conditions [10,11]. It has been used as a soil amendment [12], carbon sequestration agent [13], and adsorbent for the removal of organic and inorganic compounds (e.g., $\mathrm{NH}_{4}-\mathrm{N}, \mathrm{Cu}, \mathrm{Zn}$, and $\mathrm{Pb}$ ) in aquatic environments [14-19]. However, biochar in the form of fine powder is difficult to separate from aqueous solution after adsorbing pollutants $[10,20]$. Filtration and centrifugation steps are commonly used for this separation, but the pollutants on the biochars may desorb during the processes [21,22]. To overcome the problem of powdered biochar recovery, some studies have introduced 
magnetic properties into biochar by pure chemical (e.g., iron oxide, ferromanganese binary oxide, and iron oxy-hydroxides) immobilization $[10,11,23]$. Magnetic biochars prepared by combining iron oxide and orange peel powder indicated efficient sorption capabilities to remove organic pollutants and phosphate from an aqueous solution [10]. The adsorption capacity of salicylic acid, naproxen, and ketoprofen from aqueous solution was identified by synthesized magnetic biochars using walnut shell and ferric chloride [21]. Wang and Zhang demonstrated the adsorption capacities of Bisphenol A from wastewater by magnetic biochars synthesized from grapefruit peel and maghemite; the main adsorption mechanisms were $\mathrm{H}$-bond and $\pi-\pi$ electron-donor-acceptor interaction [23]. However, the application of pure iron oxide chemicals increases the cost and thereby reduces the economic benefits of biochar derived from waste biomass.

In this study, we developed inexpensive magnetic biochar combining raw BOF slag and biochar to explore whether the magnetic slag biochar composite can maximize the benefits of the two components. Differences in biomass types and compositions are principal factors influencing the physicochemical characteristics of biochar. The introduction of magnetic BOF slag may affect the physicochemical characteristics and performances of biochar. Research on the effect of magnetic field on physicochemical properties of aqueous solutions was also reported previously by Szatylowicz and Skoczko [24]. Therefore, this study was designed to investigate the effectiveness of magnetic slag biochar composite for $\mathrm{NH}_{4}-\mathrm{N}$ removal from aqueous solution, and to determine the physicochemical characteristics of magnetic slag biochar such as adsorption capacities, volume of surface area, surface structure, and magnetic properties.

\section{Materials and Methods}

\subsection{Materials}

Pine sawdust powder collected from Pohang National Forestry Cooperative Federation in South Korea was stored in a dried phase in an incubator $\left(30^{\circ} \mathrm{C}\right)$. BOF slag powder (Table 1) was obtained from a steel-making company (POSCO, Pohang, Korea) and used as a substrate for slag biochar complexation.

Table 1. Chemical compositions of BOF slag.

\begin{tabular}{cc}
\hline Metal Oxides & Composition (\%) \\
\hline $\mathrm{Fe}_{2} \mathrm{O}_{3}$ & 34.50 \\
$\mathrm{CaO}$ & 35.00 \\
$\mathrm{SiO}_{2}$ & 15.80 \\
$\mathrm{Al}_{2} \mathrm{O}_{3}$ & 2.90 \\
$\mathrm{MnO}$ & 2.53 \\
$\mathrm{MgO}$ & 5.10 \\
$\mathrm{Cr}_{2} \mathrm{O}_{3}$ & 0.20 \\
$\mathrm{P}_{2} \mathrm{O}_{5}$ & 2.10 \\
Others & 1.87 \\
\hline
\end{tabular}

\subsection{Preparation of Biochar}

BOF slag was ball-milled to fine powder (Air jet mill JM-LB, Dongsung Science Co., Ltd., Seoul, Korea) for effective slag biochar synthesis. Two different types of biochar were synthesized by a fixed bed pyrolysis system (Mirae SI Co., Ltd., Gwangju, Korea): pine sawdust biochar (PB) from only pine sawdust, and magnetic steel slag biochar (MSSB) from pine sawdust mixed with BOF slag $(5: 2 w / w)$ (Figure 1). The chemical composition and crystal structure of the two types of biochar were compared. The fixed bed pyrolysis system containing a quartz tube ( $25 \mathrm{~mm}$ inside diameter and $240 \mathrm{~mm}$ height) was operated as follows: each sample was located in the quartz tube; its temperature was increased from room temperature (RT) to $500{ }^{\circ} \mathrm{C}$ at $10^{\circ} \mathrm{C} / \mathrm{min}$ in nitrogen atmosphere $\left(\mathrm{N}_{2}\right.$ flow rate: $100 \mathrm{~mL} / \mathrm{min})$; maintained at that temperature $\left(500^{\circ} \mathrm{C}\right)$ for $1 \mathrm{~h}$; and then cooled to RT. 


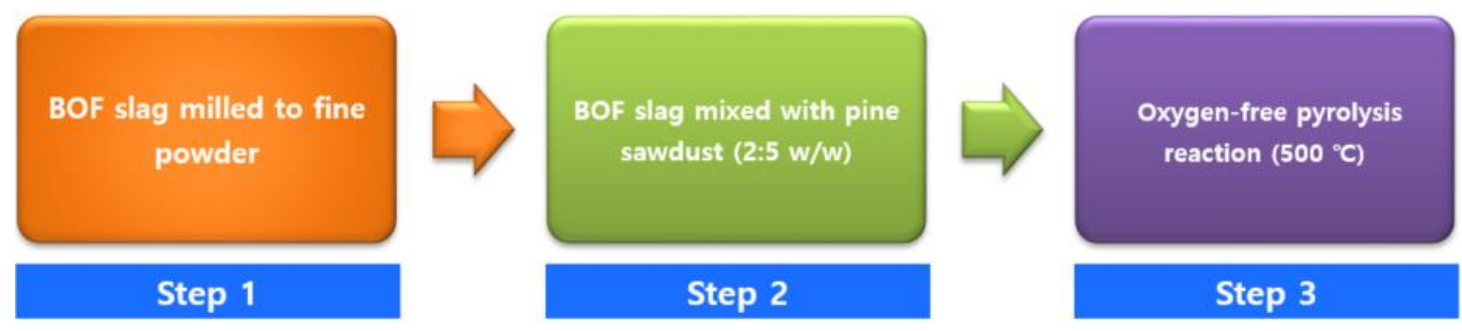

Figure 1. Preparation of MSSB from BOF slag and pine sawdust.

\subsection{Physicochemical Property Analysis of Slag Biochar Complex}

The chemical compositions of biochar were analyzed by an elemental analyzer (Vario Micro cube, Elementar Analysensysteme $\mathrm{GmbH}$, Langenselbold, Germany). A BrunauerEmmett-Teller (BET) surface analysis device (Nanoporosity-XQ analyzer, Mirae SI Co., Ltd., Gwangju, Korea) was used to measure physical adsorption capacities and surface area of gas molecules on the surface of MSSB. BET surface area and pore size distribution were analyzed by drawing an isothermal adsorption line using the Barrett-Joyner-Halenda (BJH) equation $[25,26]$. The aggregated form of MSSB was analyzed using a scanning electron microscope (SEM: JSM-6510, JEOL Co., Ltd., Tokyo, Japan) and energy-dispersive X-ray spectroscopy (EDS: Emax, Horiba, UK). To measure the magnetic properties of synthesized slag biochar, the residual magnetism of synthesized biochar was measured using a physical property measurement system (PPMS-9, Quantum Design Inc., San Diego, CA, USA). The chemical composition of MSSB was analyzed using an X-ray diffractometer (XRD: X'pert PRO MPD, Malvern PANalytical B.V., Almelo, The Netherlands).

\subsection{Batch Adsorption Experiments}

To evaluate the efficiency of MSSB as an $\mathrm{NH}_{4}-\mathrm{N}$ adsorbent, $0.1 \mathrm{~g}$ of MSSB was added to each of five Pyrex bottles containing $100 \mathrm{~mL}$ of $\mathrm{NH}_{4}-\mathrm{N}$ solution that had a concentration of $1 \leq\left[\mathrm{NH}_{4}-\mathrm{N}\right] \leq 5 \mathrm{mg} / \mathrm{L}$ and each bottle was sealed then stirred in a shaking incubator (VS-8480SF, Vision Science Co., Ltd., Daegu, Korea) at $200 \mathrm{rpm}$ and a temperature of $25^{\circ} \mathrm{C}$. At $10 \mathrm{~min}, 30 \mathrm{~min}, 1 \mathrm{~h}, 3 \mathrm{~h}, 6 \mathrm{~h}, 9 \mathrm{~h}$, and $24 \mathrm{~h}$, a sample was collected from each bottle, then $\mathrm{NH}_{4}-\mathrm{N}$ concentrations were determined according to standard methods [27]. An adsorption isotherm was measured using MSSB at $1 \leq\left[\mathrm{NH}_{4}-\mathrm{N}\right] \leq 5 \mathrm{mg} / \mathrm{L}$. The reaction time determined by adsorption kinetics was $24 \mathrm{~h}$.

\section{5. $\mathrm{NH}_{4}-\mathrm{N}$ Adsorption Kinetics and Isotherms}

$\mathrm{NH}_{4}-\mathrm{N}$ adsorption by MSSB was examined for $24 \mathrm{~h}$ to measure the time taken to reach equilibrium, and to find the adsorbed amount of $\mathrm{NH}_{4}-\mathrm{N}$ in MSSB at equilibrium. The adsorption equilibrium capacity $q_{e}[\mathrm{mg} / \mathrm{g}]$ was calculated as

$$
q_{e}=\frac{\left(C_{0}-C_{e}\right) V}{W}
$$

where $C_{0}$ and $C_{e}[\mathrm{mg} / \mathrm{L}]$ denote, respectively, the initial and equilibrium concentrations of adsorbate in the solution, $V[\mathrm{~L}]$ is the volume of solution, and $W[\mathrm{~g}]$ is the mass of adsorbent in the solution.

The kinetics of experimental data were fitted using a pseudo-first-order equation

$$
\ln \left(q_{e}-q_{t}\right)=\ln q_{e}-k_{1} t
$$

and pseudo-second-order equation

$$
\frac{1}{q_{t}}=\frac{1}{\left(k_{2}\left(q_{e}\right)^{2}\right) t}+\frac{1}{q_{e}},
$$


where $q_{t}[\mathrm{mg} / \mathrm{g}]$ represents adsorption capacity of adsorbate at time $t[\mathrm{~min}], q_{e}[\mathrm{mg} / \mathrm{g}]$ is the adsorption equilibrium capacity of adsorbate, and $k_{1}\left[\mathrm{~min}^{-1}\right]$ and $k_{2}\left[\mathrm{~g} \cdot(\mathrm{mg} \cdot \mathrm{min})^{-1}\right]$ is the adsorption- rate constants $[28,29]$.

To calculate $\mathrm{NH}_{4}-\mathrm{N}$ adsorption isotherms of MSSB, the data were fitted with the Langmuir equation

$$
q_{e}=\frac{q_{\max } K_{L} C_{e}}{1+K_{L} C_{e}}
$$

the Freundlich equation

$$
q_{e}=K_{f} c_{e} e^{1 / n},
$$

and the Temkin equation

$$
q_{e}=\frac{R T}{b} \ln \left(A \cdot C_{e}\right)=B \ln \left(A \cdot C_{e}\right),
$$

where $q_{e}[\mathrm{mg} / \mathrm{g}]$ is the amount of adsorbate adsorbed at equilibrium, $K_{L}[\mathrm{~L} / \mathrm{mg}]$ is the Langmuir constant, $K_{f}[\mathrm{~L} / \mathrm{g}]$ is the Freundlich equation constant, $q_{\max }[\mathrm{mg} / \mathrm{g}]$ represents a theoretical maximum adsorption capacity, and $C_{e}[\mathrm{mg} / \mathrm{L}]$ is the adsorbate concentration at equilibrium in the solution. $n$ is the Freundlich exponent constant, $b$ is the Temkin isotherm constant related to adsorbent-adsorbate interactions, $A[\mathrm{~L} / \mathrm{g}]$ is the Temkin isotherm equilibrium binding constant, $R=8.314[\mathrm{~J} / \mathrm{mol} \cdot \mathrm{K}]$ is the universal gas constant, $T=298 \mathrm{~K}$ is reaction temperature, and $B=R T / b[\mathrm{~J} / \mathrm{mol}]$ is a constant related to the heat of sorption [30-32]. Originpro software (version 9.0) was used to draw figures and fit isotherm curves by both linear and nonlinear regression methods.

\section{Results and Discussion}

\subsection{Physicochemical Properties of MSSB}

To observe the crystal structure of MSSB, the XRD peak patterns of PB, BOF slag powder, and MSSB were compared (Figure 2). The XRD pattern of PB showed that it is amorphous; this trait influences the structure of MSSB. XRD patterns of BOF slag powder and MSSB had five predominant peaks (Figure 2, triangles) that match the 220, 311, 400, 511, and 440 planes of magnetite (JCPDS 19-0629); this result illustrates that BOF slag powder included $\mathrm{Fe}_{3} \mathrm{O}_{4}$ and that pyrolysis successfully combined pine sawdust with BOF slag powder components.

The chemical composition and structural characterization of MSSB were identified by SEM images and EDS analysis (Figure 3). These measurements confirmed the presence of BOF slag powder on the surface of MSSB (Figure 3a). The base morphology of MSSB showed porous linked-fibrous shape, which is similar to the morphology of pine sawdust [33]. The EDS spectra showed that MSSB includes $\mathrm{Fe}, \mathrm{Ca}, \mathrm{Al}, \mathrm{Mg}, \mathrm{Mn}, \mathrm{C}$, and O (Figure 3c); most of the ions ( $\mathrm{Fe}, \mathrm{Ca}, \mathrm{Al}, \mathrm{Mg}$, and $\mathrm{Mn}$ ) in MSSB seemed to derive from $\mathrm{BOF}$ slag powder components, and most $C$ ions seemed to derive from pine sawdust.

MSSB and PB had distinct elemental compositions (CHN) and $\mathrm{pH}$ (Table 2). MSSB included BOF slag powder and therefore had less $\mathrm{C}$ than PB did and higher $\mathrm{pH}$. MSSB had smaller specific surface area, pore size, and adsorption/desorption area than PB did. Similar results were also observed under synthesized magnetic biochar condition compared to non-magnetic biochar condition although the magnetic biochar was synthesized using commercial chemicals [10]. 


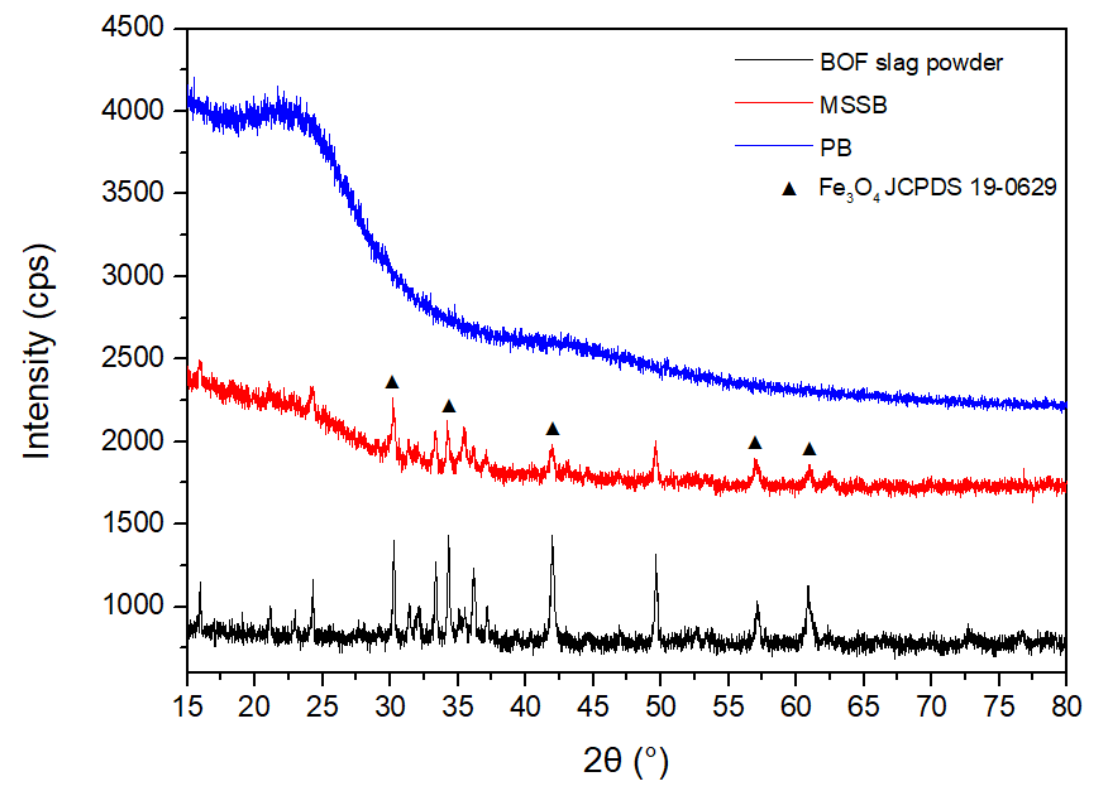

Figure 2. XRD peak patterns of $\mathrm{PB}, \mathrm{MSSB}$, and BOF slag powder.

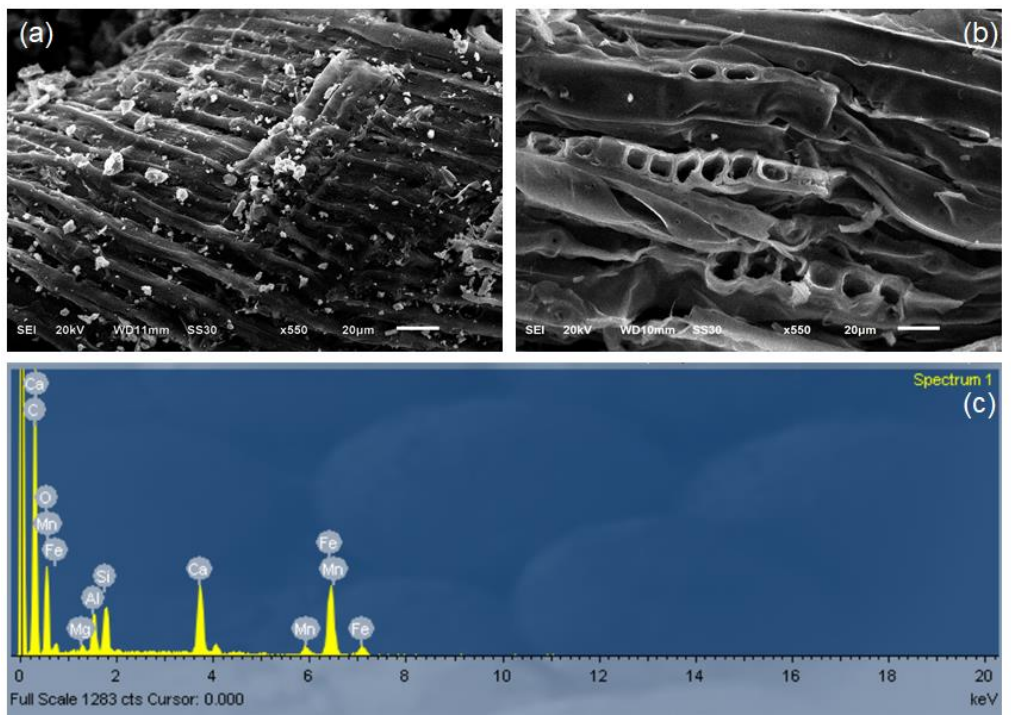

Figure 3. Scanning electron microscope (SEM) images of MSSB and PB: (a) MSSB $(\times 550)$, (b) PB $(\times 550)$, (c) energy dispersive X-ray spectroscopy (EDS) analysis of MSSB.

Table 2. Characteristics of pine sawdust biochar (PB) and magnetic steel slag biochar (MSSB).

\begin{tabular}{ccc}
\hline Material & PB & MSSB \\
\hline $\mathrm{C}(\%)$ & 75.9 & 32.7 \\
$\mathrm{H}(\%)$ & 3.1 & 2.25 \\
$\mathrm{~N}(\%)$ & 0.61 & 0.51 \\
$\mathrm{pH}$ & 8.08 & 9.89 \\
BET surface area $\left[\mathrm{m}^{2} / \mathrm{g}\right]$ & $18.21-19.13$ & $11.46-11.96$ \\
$\mathrm{BJH}$ adsorption/desorption area $\left[\mathrm{m}^{2} / \mathrm{g}\right]$ & $18.80-21.42$ & $11.84-15.66$ \\
$\mathrm{BJH}$ adsorption/desorption pore size $[\mathrm{nm}]$ & $/ 19.11-25.68$ & $/ 12.28-21.97$ \\
& $4.25-4.31$ & $3.94-3.97$ \\
& $/ 4.03-4.61$ & $/ 3.82-4.56$ \\
\hline
\end{tabular}

PPMS indicated that MSSB was paramagnetic with no external magnetism. Saturation magnetic moment of MSSB was $2.30 \mathrm{emu} / \mathrm{g}$ at 2 Tesla, which is lower than reported 
previously [20,34-36], possibly because we did not use commercial chemicals to synthesize magnetic biochars (Figure 4, Table 3).

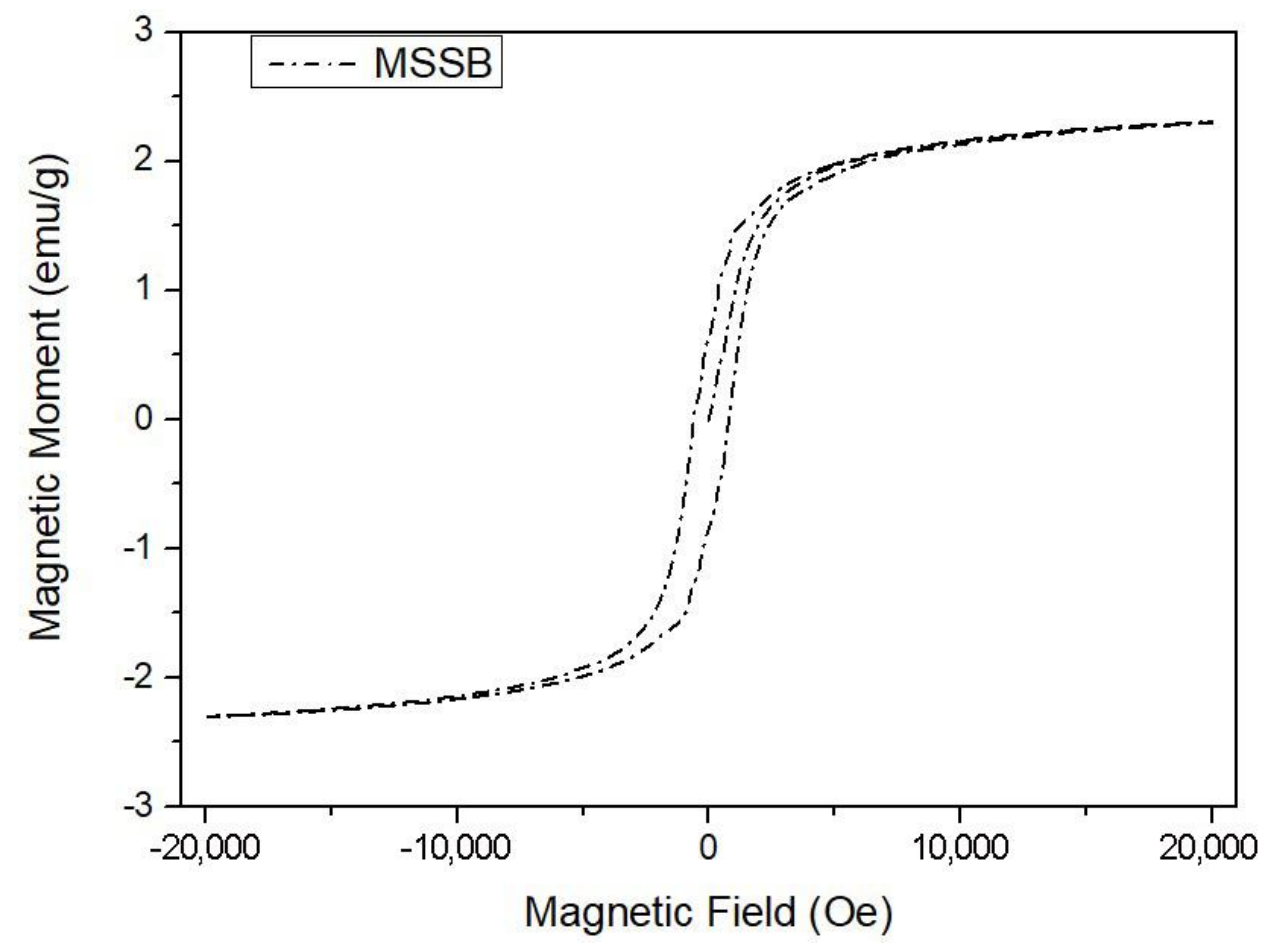

Figure 4. Magnetic hysteresis loop curve of MSSB (10,000 Oe = 1 Tesla).

Table 3. The saturation magnetic moment of magnetic biochar.

\begin{tabular}{cccc}
\hline Base Materials & Additional Components & Saturation Magnetic Moment [emu/g] & Reference \\
\hline Rice hull & $\mathrm{Fe}\left(\mathrm{C}_{5} \mathrm{H}_{7} \mathrm{O}_{2}\right)_{3}$ & $11.6-14.3$ & {$[20]$} \\
Red cedar (Thuja plicata) & $\mathrm{FeCl}_{3} \cdot 6 \mathrm{H}_{2} \mathrm{O} / \mathrm{FeSO}_{4} \cdot 7 \mathrm{H}_{2} \mathrm{O}$ & $10-25$ & {$[33]$} \\
Spent coffee ground & $\mathrm{FeCl}_{3}$ & $3.89-8.08$ & {$[34]$} \\
Long-thorn kiawe (Prosopis juliflora) & $\mathrm{Ni}\left(\mathrm{NO}_{3}\right)_{2}$ & 0.087 & 2.3 \\
Pine tree sawdust & $\mathrm{BOF} \mathrm{slag}$ & $35]$ & This study \\
\hline
\end{tabular}

\section{2. $\mathrm{NH}_{4}-\mathrm{N}$ Adsorption by MSSB in Aqueous Solution}

Time-dependent $\mathrm{NH}_{4}-\mathrm{N}$ adsorption by MSSB and PB was investigated using solutions that had initial $1 \leq\left[\mathrm{NH}_{4}-\mathrm{N}\right] \leq 5 \mathrm{mg} / \mathrm{L}$. All $\mathrm{NH}_{4}-\mathrm{N}$ adsorption capacities of MSSB increased as time increased to $24 \mathrm{~h}$. The adsorption capacities of $\mathrm{NH}_{4}-\mathrm{N}$ at equilibrium by MSSB increased from 1.0 to $2.72 \mathrm{mg} / \mathrm{g}$ as the initial $\mathrm{NH}_{4}-\mathrm{N}$ concentration increased from 1 to $5 \mathrm{mg} / \mathrm{L}$ (Figure 5a). Similarly, the adsorption capacities of $\mathrm{NH}_{4}-\mathrm{N}$ at equilibrium by $\mathrm{PB}$ increased from 1.0 to $2.91 \mathrm{mg} / \mathrm{g}$ as the initial $\mathrm{NH}_{4}-\mathrm{N}$ concentration increased from 1 to $5 \mathrm{mg} / \mathrm{L}$ (Figure $5 \mathrm{~b}$ ). However, the maximum $\mathrm{NH}_{4}-\mathrm{N}$ adsorption capacity of MSSB was lower than that of $\mathrm{PB}$. This might be attributed to smaller surface area and pore size at MSSB than at PB (Table 2) or to the considerable amount of metal oxides derived from BOF slag at MSSB (Table 1). Biochars can carry a lot of negative charges on the surface [15] and some metal oxides of $\mathrm{BOF}$ slag such as $\mathrm{MgO}$ and $\mathrm{CaO}$ can be dissolved in aqueous solution, which could form cations around MSSB $[37,38]$. Consequently, the metal cations seemed to compete with $\mathrm{NH}_{4}-\mathrm{N}$ for the adsorption sites of MSSB, resulting in a decrease in the capacity of adsorbent material for $\mathrm{NH}_{4}-\mathrm{N}$ [39]. 

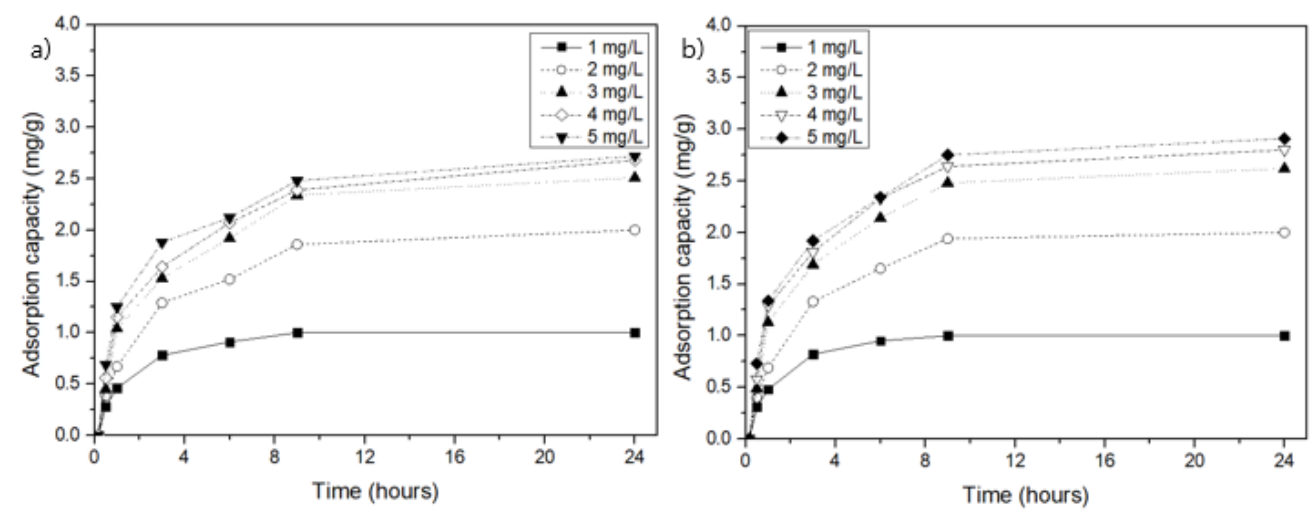

Figure 5. $\mathrm{NH}_{4}-\mathrm{N}$ adsorption capacities of MSSB and $\mathrm{PB}$ at different initial $\mathrm{NH}_{4}-\mathrm{N}$ concentrations: (a) MSSB, (b) PB.

Previous results have shown that $\mathrm{NH}_{4}-\mathrm{N}$ adsorption capacities by biochars can be influenced by types of materials and initial $\mathrm{NH}_{4}-\mathrm{N}$ concentrations. Biochars derived from wheat straw, corn straw, or peanut shells obtained a maximum $\mathrm{NH}_{4}-\mathrm{N}$ adsorption capacity of $2.4 \mathrm{mg} / \mathrm{g}$ at initial $\left[\mathrm{NH}_{4}-\mathrm{N}\right]=50 \mathrm{mg} / \mathrm{L}$ [11]. Rice straw biochars achieved a maximum adsorption capacity of $2.67 \mathrm{mg} / \mathrm{g}$ at initial $\left[\mathrm{NH}_{4}-\mathrm{N}\right]=50 \mathrm{mg} / \mathrm{L}$ [16]. Pinechip biochars achieved a maximum $\mathrm{NH}_{4}-\mathrm{N}$ adsorption capacity of $0.52 \mathrm{mg} / \mathrm{g}$ at initial $\left[\mathrm{NH}_{4}-\mathrm{N}\right]=79 \mathrm{mg} / \mathrm{L}$ [40]. Biochars prepared from sorghum distillers grain attained a $\mathrm{NH}_{4}-\mathrm{N}$ adsorption capacity of $2.06 \mathrm{mg} / \mathrm{g}$ at initial $\left[\mathrm{NH}_{4}-\mathrm{N}\right]=100 \mathrm{mg} / \mathrm{L}$ [41]. Wood chip biochars obtained a maximum $\mathrm{NH}_{4}-\mathrm{N}$ adsorption capacity of $0.96 \mathrm{mg} / \mathrm{g}$ at initial $\left[\mathrm{NH}_{4}-\mathrm{N}\right]=80 \mathrm{mg} / \mathrm{L}$ [42]. Various biochars indicated the potential to remove $\mathrm{NH}_{4}-\mathrm{N}$ from an aqueous solution. The $\mathrm{NH}_{4}-\mathrm{N}$ adsorption capacities by MSSB in this study were comparable to previous studies.

$\mathrm{NH}_{4}-\mathrm{N}$ can be adsorbed by three mechanisms: (1) surface complexation between $\mathrm{NH}_{4}-\mathrm{N}$ and surface hydroxyl species, (2) surface co-precipitation as $\mathrm{Mg}\left(\mathrm{NH}_{4}\right) \mathrm{PO}_{4}$ with magnesium from biochars and phosphate from biochars or solutions, and (3) formation of $\mathrm{NH}_{4}-\mathrm{C}$ bonds between $\mathrm{NH}_{4}-\mathrm{N}$ and delocalized lone pair electrons in biochars [43]. In this study, MSSB includes BOF slag powder that contains $5.1 \% \mathrm{MgO}$ and $2.1 \% \mathrm{P}_{2} \mathrm{O}_{5}$ (Table 1), so surface precipitation in the form of $\mathrm{Mg}\left(\mathrm{NH}_{4}\right) \mathrm{PO}_{4}$ seems likely to be a possible mechanism of $\mathrm{NH}_{4}-\mathrm{N}$ adsorption. $\mathrm{MgO}$ hydration process can be described as follows [37]:

$$
\mathrm{MgO}_{(\mathrm{s})}+\mathrm{H}_{2} \mathrm{O}_{(\mathrm{l})} \rightarrow \mathrm{MgOH}_{(\text {surface })}^{+}+\mathrm{OH}^{-} \rightarrow \mathrm{Mg}^{2+}+2 \mathrm{OH}^{-}
$$

Water diffuses inside porous $\mathrm{MgO}$ particles, adsorbs, and reacts on the surface, then $\mathrm{Mg}^{2+}$ and $\mathrm{OH}^{-}$ions are released. The dissolution process causes high supersaturation, which induces rapid $\mathrm{Mg}\left(\mathrm{NH}_{4}\right) \mathrm{PO}_{4}$ precipitation according to the following reaction and $\mathrm{P}_{2} \mathrm{O}_{5}$ is easily reacted with water, releasing $\mathrm{H}_{3} \mathrm{PO}_{4}$ [44]:

$$
\mathrm{Mg}^{2+}+\mathrm{NH}_{4}^{+}+\mathrm{H}_{n} \mathrm{PO}_{4}^{\mathrm{n}-3}+6 \mathrm{H}_{2} \mathrm{O} \rightarrow \mathrm{MgNH}_{4} \mathrm{PO}_{4} \cdot 6 \mathrm{H}_{2} \mathrm{O}+\mathrm{nH}^{+}
$$

In addition, $\mathrm{NH}_{4}-\mathrm{N}$ adsorption to biochars can be explained as an electrostatic reaction and $\mathrm{NH}_{4}{ }^{+}$in aqueous solutions can displace $\mathrm{Ca}^{2+}$ present on biochar surfaces [45]. The BOF slag powder from which MSSB was synthesized included $35.0 \% \mathrm{CaO}$, which easily reacts with water sequentially: $\mathrm{Ca}(\mathrm{OH})_{2}$ is produced, then the $\mathrm{Ca}(\mathrm{OH})_{2}$ is dissociated into $\mathrm{Ca}^{2+}$ and $\mathrm{OH}^{-}[38,46]$. Therefore, $\mathrm{Ca}^{2+}$ displacement may also contribute to $\mathrm{NH}_{4}-\mathrm{N}$ adsorption (Table 1).

\subsection{Kinetics and Isotherms of MSSB}

To describe $\mathrm{NH}_{4}-\mathrm{N}$ adsorption equilibrium data, pseudo-first order and pseudosecond order kinetic models were fitted using linear regression analysis (Figure 6, Table 4). Compared to the pseudo-first kinetic model, the correlation coefficients from the pseudo- 
second kinetic model were higher for 1, 2, and $5 \mathrm{mg} / \mathrm{L}$ of initial $\mathrm{NH}_{4}-\mathrm{N}$ concentration and similar for 3 and $4 \mathrm{mg} / \mathrm{L}$ of initial $\mathrm{NH}_{4}-\mathrm{N}$ concentration; this result indicates that the pseudo-second kinetic model showed mostly higher correlation with the experimental data than the pseudo-first kinetic model. A similar result was reported previously [47]; the pseudo-second kinetic model was better fit for experimental data than the pseudofirst kinetic model when pine sawdust and wheat straw biochars were used for $\mathrm{NH}_{4}-\mathrm{N}$ adsorption. This trend may suggest a mechanism in which a fast initial step that is limited by general diffusion is followed by a slow second step that is limited by diffusion in small pores or by slow adsorption [48].

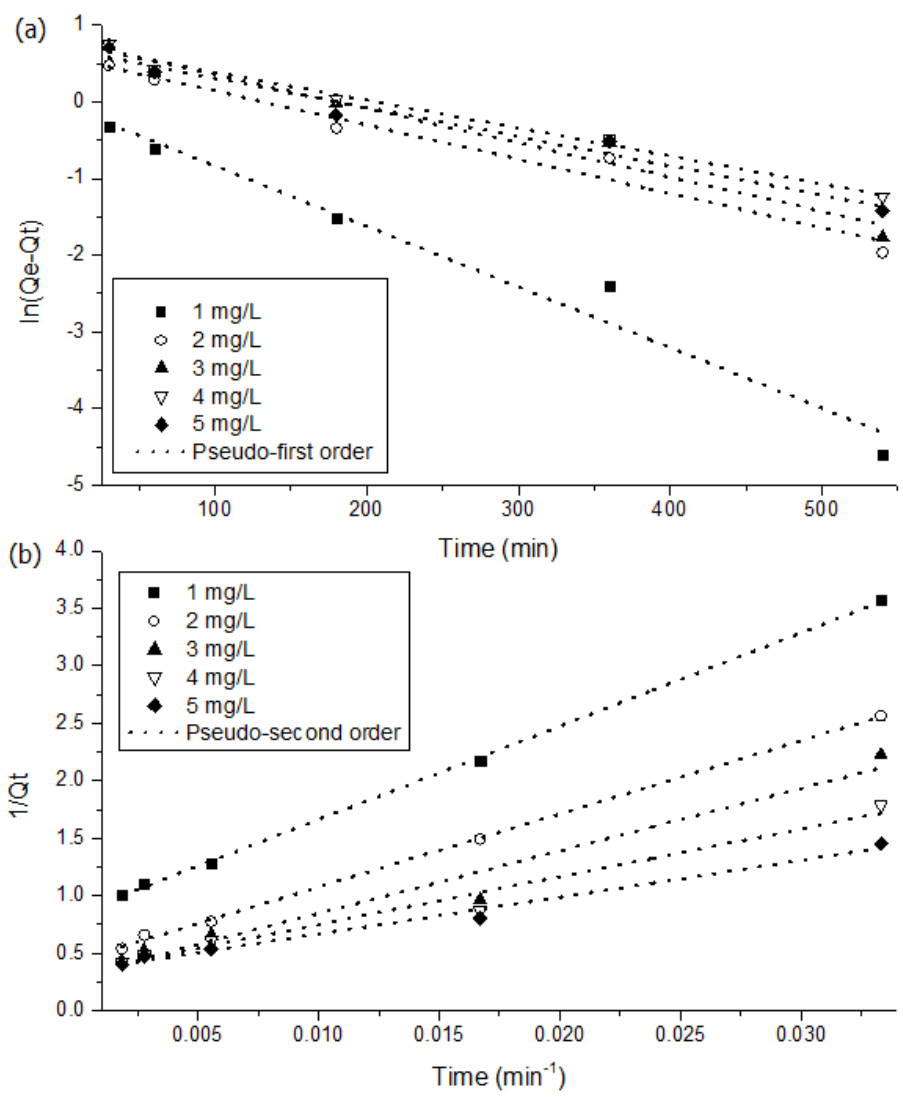

Figure 6. Linear adsorption kinetic models of $\mathrm{NH}_{4}-\mathrm{N}$ adsorption on MSSB at different initial $\mathrm{NH}_{4}-\mathrm{N}$ concentrations: (a) Pseudo-first order equation, (b) Pseudo-second order equation.

Table 4. Parameters of kinetic model for $\mathrm{NH}_{4}-\mathrm{N}$ adsorption onto MSSB.

\begin{tabular}{|c|c|c|c|c|c|c|c|}
\hline \multirow{2}{*}{$\begin{array}{c}\text { Initial Conc. } \\
{[\mathrm{mg} / \mathrm{L}]}\end{array}$} & \multirow{2}{*}{$\begin{array}{c}q_{e}, \exp \\
{[\mathrm{mg} / \mathrm{g}]}\end{array}$} & \multicolumn{3}{|c|}{ Pseudo-First Order } & \multicolumn{3}{|c|}{ Pseudo-Second Order } \\
\hline & & $\begin{array}{c}\mathrm{q}_{\mathrm{e}, \mathrm{cal}} \\
{[\mathrm{mg} / \mathrm{g}]}\end{array}$ & $\begin{array}{c}\mathbf{k}_{\mathbf{1}} \\
{[\mathrm{mg} / \mathrm{g}]}\end{array}$ & $r^{2}$ & $\begin{array}{c}\mathrm{q}_{\mathrm{e}, \mathrm{cal}} \\
{[\mathrm{mg} / \mathrm{g}]}\end{array}$ & $\begin{array}{c}\mathrm{k}_{2} \\
{[\mathrm{~g} / \mathrm{mg} \cdot \mathrm{min}]}\end{array}$ & $\mathbf{r}^{2}$ \\
\hline 1.000 & 1.000 & 0.956 & 0.008 & 0.963 & 1.177 & 0.009 & 0.999 \\
\hline 2.000 & 2.000 & 1.800 & 0.004 & 0.958 & 2.276 & 0.003 & 0.999 \\
\hline 3.000 & 2.510 & 2.228 & 0.004 & 0.955 & 3.299 & 0.002 & 0.950 \\
\hline 4.000 & 2.680 & 2.113 & 0.004 & 0.983 & 3.006 & 0.003 & 0.965 \\
\hline 5.000 & 2.720 & 1.991 & 0.004 & 0.958 & 2.898 & 0.004 & 0.983 \\
\hline
\end{tabular}

Langmuir, Freundlich, and Temkin adsorption isotherm models were applied to determine the mechanism of $\mathrm{NH}_{4}-\mathrm{N}$ adsorption onto MSSB (Figure 7). The isotherm parameters (Table 5) show that the equilibrium data were fit best by the Temkin isotherm; it had $B$ (heat of adsorption) $>0$; this result suggests that $\mathrm{NH}_{4}-\mathrm{N}$ adsorption is exothermic (Table 5) [49]. The type of adsorption can be classified according to the value of $B(\mathrm{~J} / \mathrm{mol}$, 
heat of adsorption): if $B<4.2 \mathrm{~kJ} / \mathrm{mol}$, the adsorption reaction is physical adsorption, whereas if $B$ is $84-210 \mathrm{~kJ} / \mathrm{mol}$, the adsorption reaction is chemical adsorption [50]. In this study, $B<4.2 \mathrm{~kJ} / \mathrm{mol}$, so $\mathrm{NH}_{4}-\mathrm{N}$ adsorption on MSSB seemed to be physical adsorption; this adsorption can occur by weak electrostatic interactions such as Van der Waals interactions, dipole-dipole forces, and London forces [51]. Therefore, the possible mechanism of $\mathrm{NH}_{4}-\mathrm{N}$ adsorption on MSSB is electrostatic interaction between $\mathrm{NH}_{4}{ }^{+}$ion and negative charge on the surface of MSSB, which is due to the dissociation of oxygen-containing functional groups of biochar; this causes electrostatic attraction between biochar and positively charged molecules [52].

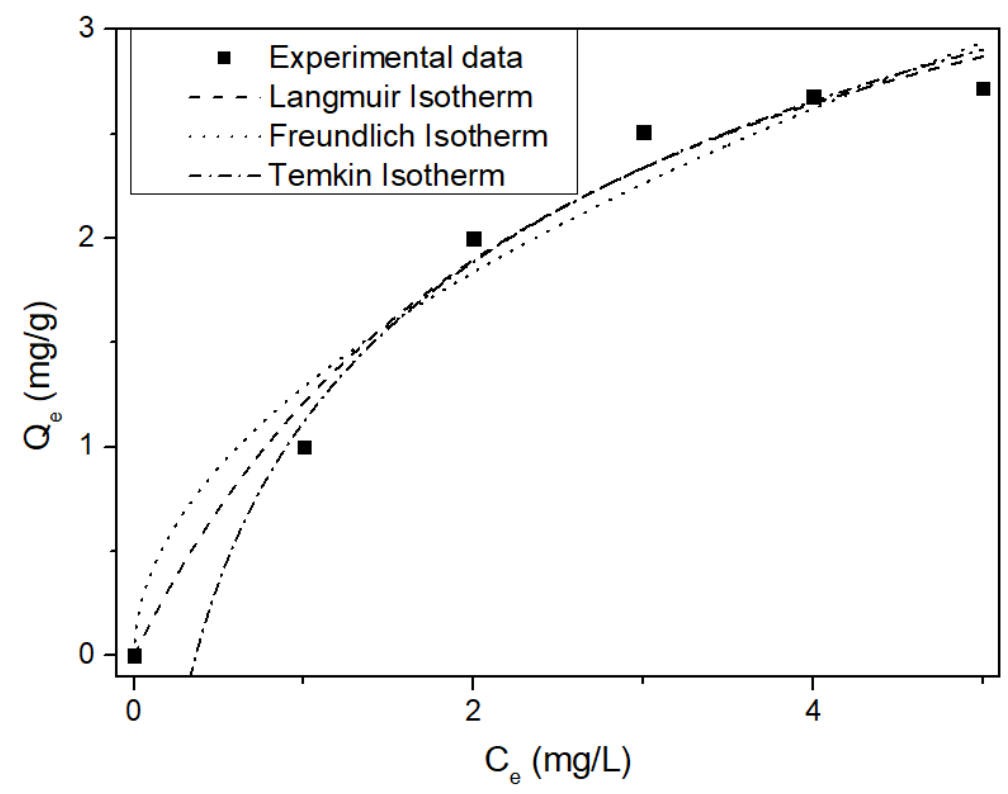

Figure 7. Non-linear isotherms for $\mathrm{NH}_{4}-\mathrm{N}$ adsorption on MSSB at different initial $\mathrm{NH}_{4}-\mathrm{N}$ concentrations.

Table 5. Parameters of Langmuir, Freundlich, and Temkin isotherm models for $\mathrm{NH}_{4}-\mathrm{N}$ adsorption onto MSSB.

\begin{tabular}{cccccc}
\hline \multicolumn{2}{c}{ Langmuir } & \multicolumn{2}{c}{ Freundlich } & \multicolumn{2}{c}{ Temkin } \\
\hline $\mathrm{K}_{\mathrm{L}}[\mathrm{L} / \mathrm{mg}]$ & 0.384 & $\mathrm{~K}_{\mathrm{f}}[\mathrm{mg} / \mathrm{g}]$ & 1.287 & $\mathrm{~A}_{\mathrm{r}}[\mathrm{L} / \mathrm{g}]$ & 2.749 \\
$\mathrm{q}_{\max }[\mathrm{mg} / \mathrm{g}]$ & 4.366 & $\mathrm{n}$ & 1.949 & $\mathrm{~B}[\mathrm{~J} / \mathrm{mol}]$ & 2047.934 \\
$\mathrm{r}^{2}$ & 0.977 & $\mathrm{r}^{2}$ & 0.954 & $\mathrm{r}^{2}$ & 0.981 \\
\hline
\end{tabular}

The Langmuir isotherm model also showed a high correlation coefficient for $\mathrm{NH}_{4}-\mathrm{N}$ adsorption (Table 5) with a maximum adsorption capacity $4.366 \mathrm{mg} / \mathrm{g}$. In general, this model is based on limited monolayer adsorption, so $\mathrm{NH}_{4}-\mathrm{N}$ adsorption on MSSB might be more monolayer adsorption than multilayer adsorption [53].

\section{Conclusions}

This study demonstrated the $\mathrm{NH}_{4}-\mathrm{N}$ adsorption capacities and magnetic properties of biochars synthesized from low-cost steel slag waste and pine sawdust. MSSB had large specific surface area, micro-sized pores, and good magnetic properties. The maximum adsorption capacity of $\mathrm{NH}_{4}-\mathrm{N}$ by MSSB was $2.72 \mathrm{mg} / \mathrm{g}$. Although the maximum $\mathrm{NH}_{4}-\mathrm{N}$ adsorption capacity of PB was higher than that of MSSB, the difference was not great. Adsorption of $\mathrm{NH}_{4}-\mathrm{N}$ onto MSSB illustrated that the pseudo-second order kinetic model and Temkin isotherm model were well fit for the experimental data. These results indicated the potential of magnetic biochars using low-cost steel slag waste for $\mathrm{NH}_{4}-\mathrm{N}$ removal from an aqueous solution, but their $\mathrm{NH}_{4}-\mathrm{N}$ adsorption capacities and magnetic properties can be influenced by functional parameters such as $\mathrm{NH}_{4}-\mathrm{N}$ concentration, the ratio of steel 
slag to pine sawdust or pyrolysis temperature. Therefore, a more detailed investigation into functional parameters is required for strengthening commercial potential. In addition, further studies on the effects of addition of MSSB containing BOF slag, pine sawdust, and $\mathrm{NH}_{4}-\mathrm{N}$ to soil should be conducted to determine its effects on plant growth in practical applications as a soil amendment.

Author Contributions: J.M.P. and H.U.C. conceived the experiments and G.K. performed the experiments. G.K., S.M.K. and H.U.C. analyzed the data. G.K. and H.U.C. wrote the manuscript. Y.M.K. reviewed the manuscript. H.U.C. and J.M.P. revised the manuscript. All authors have read and agreed to the published version of the manuscript.

Funding: This research was a part of the project titled 'Green Science Program' funded by POSCO, Korea. This research was also supported by "Human Resources Program in Energy Technology" of the Korea Institute of Energy Technology Evaluation and Planning (KETEP), granted financial resource from the Ministry of Trade, Industry \& Energy, Republic of Korea (No. 20194030202330).

Data Availability Statement: Data is contained within the article.

Conflicts of Interest: The authors declare no conflict of interest.

\section{References}

1. Korea Iron \& Steel Association Crude Steel Production. Available online: https://www.kosa.or.kr/eng/statistics/production_20 11.jsp (accessed on 4 November 2020).

2. Min, T.; Kim, H.; Lim, H. Characteristics of Electric Arc Furnace Oxidized Slag and Domestic and International Research Trend. Mag. RCR 2019, 14, 40-47.

3. Choi, J.-S. The Status and Utilization Prospect of Steel Making Slag. Rev. Archit. Build. Sci. 2012, 56, 18-21.

4. Xue, P.; He, D.; Xu, A.; Gu, Z.; Yang, Q.; Engström, F.; Björkman, B. Modification of Industrial BOF Slag: Formation of MgFe $\mathrm{B}_{4}$ and Recycling of Iron. J. Alloy. Compd. 2017, 712, 640-648. [CrossRef]

5. Kim, W. Current State of Recycling and Properties of Steel Slag. Mag. RCR 2014, 9, 11-15.

6. Öner, M.; Erdogdu, K.; Günlü, A. Effect of Components Fineness on Strength of Blast Furnace Slag Cement. Cem. Concr. Res. 2003, 33, 463-469. [CrossRef]

7. Bellmann, F.; Stark, J. Activation of Blast Furnace Slag by a New Method. Cem. Concr. Res. 2009, 39, 644-650. [CrossRef]

8. Naidu, T.S.; Sheridan, C.M.; van Dyk, L.D. Basic Oxygen Furnace Slag: Review of Current and Potential Uses. Miner. Eng. 2020, 149, 106234. [CrossRef]

9. Wen, T.; Yang, L.; Dang, C.; Yang, M.; Miki, T.; Bai, H.; Nagasaka, T. Effect of Modified Basic Oxygen Furnace Slag on the controlled Release of Nitrate Nitrogen and the Functional Microbial Community in Soil. J. Environ. Manag. 2020, $261,110191$. [CrossRef]

10. Chen, B.; Chen, Z.; Lv, S. A Novel Magnetic Biochar Efficiently Sorbs Organic Pollutants and Phosphate. Bioresour. Technol. 2011, 102, 716-723. [CrossRef]

11. Gai, X.; Wang, H.; Liu, J.; Zhai, L.; Liu, S.; Ren, T.; Liu, H. Effects of Feedstock and Pyrolysis Temperature on Biochar Adsorption of Ammonium and Nitrate. PLoS ONE 2014, 9, 1-19. [CrossRef]

12. Liang, B.; Lehmann, J.; Solomon, D.; Kinyangi, J.; Grossman, J.; O’Neill, B.; Skjemstad, J.O.; Thies, J.; Luizão, F.J.; Petersen, J.; et al. Black Carbon Increases Cation Exchange Capacity in Soils. Soil Sci. Soc. Am. J. 2006, 70, 1719-1730. [CrossRef]

13. Lehmann, J.; Joseph, S. Biochar for Environmental Management, 2nd ed.; Earthscan: London, UK, 2009.

14. Lee, Y.-G.; Shin, J.; Kwak, J.; Kim, S.; Son, C.; Cho, K.H.; Chon, K. Effects of NaOH Activation on Adsorptive Removal of Herbicides by Biochars Prepared from Ground Coffee Residues. Energies 2021, 14, 1297. [CrossRef]

15. Zhao, S.; Ta, N.; Wang, X. Absorption of $\mathrm{Cu}(\mathrm{II})$ and $\mathrm{Zn}(\mathrm{II})$ from Aqueous Solutions onto Biochars Derived from Apple Tree Branches. Energies 2020, 13, 3498. [CrossRef]

16. Park, M.H.; Jeong, S.; Kim, J.Y. Adsorption of NH3-N onto Rice Straw-Derived Biochar. J. Environ. Chem. Eng. 2019, 7, 103039. [CrossRef]

17. Hestrin, R.; Enders, A.; Lehmann, J. Ammonia Volatilization from Composting with Oxidized Biochar. J. Environ. Qual. 2020, 49, 1690-1702. [CrossRef]

18. Shin, J.; Choi, E.; Jang, E.S.; Hong, S.G.; Lee, S.R.; Ravindran, B. Adsorption Characteristics of Ammonium Nitrogen and Plant Responses to Biochar Pellet. Sustainability 2018, 10, 1331. [CrossRef]

19. Li, S.; Ho, S.-H.; Hua, T.; Zhou, Q.; Li, F.; Tang, J. Sustainable Biochar as Electrocatalysts for the Oxygen Reduction Reaction in Microbial Fuel Cells. Green Energy Environ. 2020. [CrossRef]

20. Yan, L.; Kong, L.; Qu, Z.; Li, L.; Shen, G. Magnetic Biochar Decorated with ZnS Nanocrytals for Pb (II) Removal. ACS Sustain. Chem. Eng. 2015, 3, 125-132. [CrossRef]

21. Anfar, Z.; Zbair, M.; Ait Ahsiane, H.; Jada, A.; El Alem, N. Microwave Assisted Green Synthesis of $\mathrm{Fe}_{2} \mathrm{O}_{3} / \mathrm{Biochar}_{\text {for Ultrasonic }}$ Removal of Nonsteroidal Anti-inflammatory Pharmaceuticals. RSC Adv. 2020, 10, 11371-11380. [CrossRef] 
22. Yi, Y.; Tu, G.; Zhao, D.; Tsang, P.E.; Fang, Z. Biomass Waste Components Significantly Influence the Removal of Cr(VI) Using Magnetic Biochar Derived from Four Types of Feedstocks and Steel Pickling Waste Liquor. Chem. Eng. J. 2019, 360, $212-220$. [CrossRef]

23. Wang, J.; Zhang, M. Adsorption Characteristics and Mechanism of Bisphenol a by Magnetic Biochar. Int. J. Environ. Res. Public Health 2020, 17, 1075. [CrossRef]

24. Szatyłowicz, E.; Skoczko, I. The Use of Activated Alumina and Magnetic Field for the Removal Heavy Metals from Water. J. Ecol. Eng. 2018, 19, 61-67. [CrossRef]

25. Brunauer, S.; Emmett, P.H.; Teller, E. Adsorption of Gases in Multimolecular Layers. J. Am. Chem. Soc. 1938, 60, 309-319. [CrossRef]

26. Barrett, E.P.; Joyner, L.G.; Halenda, P.P. The Determination of Pore Volume and Area Distributions in Porous Substances. I. Computations from Nitrogen Isotherms. J. Am. Chem. Soc. 1951, 73, 373-380. [CrossRef]

27. Clesceri, L.S.; Greenburg, A.E.; Eaton, A.D. Standard Methods for the Examination of Water and Wastewater; American Public Health Association: Washington, DC, USA, 1998.

28. Tavlieva, M.P.; Genieva, S.D.; Georgieva, V.G.; Vlaev, L.T. Kinetic Study of Brilliant Green Adsorption from Aqueous Solution onto White rice Husk Ash. J. Colloid Interface Sci. 2013, 409, 112-122. [CrossRef] [PubMed]

29. Ho, Y.S.; McKay, G. Pseudo-second Order Model for Sorption Processes. Process. Biochem. 1999, 34, 451-465. [CrossRef]

30. Langmuir, I. The Adsorption of Gases on Plane Surfaces of Glass, Mica and Platinum. J. Am. Chem. Soc. 1918, 40, 1361-1403. [CrossRef]

31. Freundlich, H.M.F. Over the Adsorption in Solution. J. Phys. Chem. 1906, 57, 1100-1107.

32. Khandelwal, A.; Narayanan, N.; Varghese, E.; Gupta, S. Linear and Nonlinear Isotherm Models and Error Analysis for the Sorption of Kresoxim-Methyl in Agricultural Soils of India. Bull. Environ. Contam. Toxicol. 2020, 104, 503-510. [CrossRef]

33. Musapatika, E.T.; Singh, R.; Moodley, K.; Nzila, C.; Onyango, M.S.; Ochieng, A. Cobalt Removal from Wastewater Using Pine Sawdust. Afr. J. Biotechnol. 2012, 11, 9407-9415. [CrossRef]

34. Wan, X.; Li, C.; Parikh, S.J. Simultaneous Removal of Arsenic, Cadmium, and Lead from Soil by Iron-modified Magnetic Biochar. Environ. Pollut. 2020, 261, 114157. [CrossRef]

35. Cho, D.W.; Yoon, K.; Kwon, E.E.; Biswas, J.K.; Song, H. Fabrication of Magnetic Biochar as a Treatment Medium for As(V) via Pyrolysis of FeCl3-Pretreated Spent Coffee Ground. Environ. Pollut. 2017, 229, 942-949. [CrossRef]

36. Saravanakumar, R.; Muthukumaran, K.; Selvaraju, N. Enhanced Pb (II) Ions Removal by Using Magnetic NiO/Biochar Composite. Mater. Res. Express 2019, 6, 105504. [CrossRef]

37. Stolzenburg, P.; Capdevielle, A.; Teychené, S.; Biscans, B. Struvite Precipitation with MgO as a Precursor: Application to Wastewater Treatment. Chem. Eng. Sci. 2015, 133, 9-15. [CrossRef]

38. Criado, Y.A.; Alonso, M.; Abanades, J.C. Kinetics of the $\mathrm{CaO} / \mathrm{Ca}(\mathrm{OH})_{2}$ Hydration/Dehydration Reaction for Thermochemical Energy Storage Applications. Ind. Eng. Chem. Res. 2014, 53, 12594-12601. [CrossRef]

39. Lu, H.; Zhang, W.; Yang, Y.; Huang, X.; Wang, S.; Qiu, R. Relative Distribution of Pb2+ Sorption Mechanisms by Sludge-derived Biochar. Water Res. 2012, 46, 854-862. [CrossRef]

40. Hina, K.; Hedley, M.; Camps-Arbestain, M.; Hanly, J. Comparison of Pine Bark, Biochar and Zeolite as Sorbents for NH4+-N Removal from Water. CLEAN Soil Air Water 2015, 43, 86-91. [CrossRef]

41. Hsu, D.; Lu, C.; Pang, T.; Wang, Y.; Wang, G. Adsorption of Ammonium Nitrogen from Aqueous Solution on Chemically Activated Biochar Prepared from Sorghum Distillers Grain. Appl. Sci. 2019, 9, 5249. [CrossRef]

42. Begum, S.A.; Golam Hyder, A.H.M.; Hicklen, Q.; Crocker, T.; Oni, B. Adsorption Characteristics of Ammonium onto Biochar from an Aqueous Solution. J. Water Supply Res. Technol. Aqua 2021, 70, 113-122. [CrossRef]

43. Fan, R.; Chen, C.L.; Lin, J.Y.; Tzeng, J.H.; Huang, C.; Dong, C.; Huang, C.P. Adsorption Characteristics of Ammonium Ion onto Hydrous Biochars in Dilute Aqueous Solutions. Bioresour. Technol. 2019, 272, 465-472. [CrossRef] [PubMed]

44. Meier, M.S. Phosphorus (V) Oxide. Encycl. Reagents Org. Synth. 2001. [CrossRef]

45. Fidel, R.B.; Laird, D.A.; Spokas, K.A. Sorption of Ammonium and Nitrate to Biochars is Electrostatic and pH-Dependent. Sci. Rep. 2018, 8, 1-10. [CrossRef]

46. Safavi, K.; Nakayama, T.A. Influence of Mixing Vehicle on Dissociation of Calcium Hydroxide in Solution. J. Endod. 2000, 26, 649-651. [CrossRef] [PubMed]

47. Yang, H.I.; Lou, K.; Rajapaksha, A.U.; Ok, Y.S.; Anyia, A.O.; Chang, S.X. Adsorption of Ammonium in Aqueous Solutions by Pine Sawdust and Wheat Straw Biochars. Environ. Sci. Pollut. Res. 2018, 25, 25638-25647. [CrossRef] [PubMed]

48. Simonin, J.P. On the Comparison of Pseudo-first Order and Pseudo-second Order Rate Laws in the Modeling of Adsorption Kinetics. Chem. Eng. J. 2016, 300, 254-263. [CrossRef]

49. Al-Ghouti, M.A.; Da'ana, D.A. Guidelines for the Use and Interpretation of Adsorption Isotherm Models: A Review. J. Hazard. Mater. 2020, 393, 122383. [CrossRef]

50. Kim, T.Y.; Park, S.K.; Cho, S.Y.; Kim, H.B.; Kang, Y.; Kim, S.D.; Kim, S.J. Adsorption of Heavy Metals by Brewery Biomass. Korean J. Chem. Eng. 2005, 22, 91-98. [CrossRef]

51. Sims, R.A.; Harmer, S.L.; Quinton, J.S. The Role of Physisorption and Chemisorption in the Oscillatory Adsorption of Organosilanes on Aluminium Oxide. Polymers 2019, 11, 410. [CrossRef] 
52. Enaime, G.; Baçaoui, A.; Yaacoubi, A.; Lübken, M. Biochar for Wastewater Treatment-Conversion Technologies and Applications. Appl. Sci. 2020, 10, 3492. [CrossRef]

53. Saadi, R.; Saadi, Z.; Fazaeli, R.; Fard, N.E. Monolayer and Multilayer Adsorption Isotherm Models for Sorption from Aqueous Media. Korean J. Chem. Eng. 2015, 32, 787-799. [CrossRef] 